\title{
Synopsis of European Neogene freshwater gastropod localities: updated stratigraphy and geography
}

\author{
Thomas A. Neubauer, Elisavet Georgopoulou, Andreas Kroh, \\ Mathias Harzhauser, Oleg Mandic, and Daniela Esu
}

\begin{abstract}
The last overview of Cenozoic localities with records of freshwater gastropods was provided more than 80 years ago. Since then, a wealth of new information has been published: new localities have been discovered and fundamental changes occurred in regional stratigraphy. In addition, many localities are still attributed to erroneous or outdated stratigraphical concepts even in recent papers. Geopolitical evolution of Europe has, furthermore, led to name changes and confusion regarding the exact origin of samples in collections. Here we provide a fully georeferenced dataset for almost all published Miocene and Pliocene freshwater gastropod localities $(2,930)$, including updated stratigraphic data where possible. This basic update will serve as an essential fundament for any future work related to the freshwater deposits and respective faunas in general.
\end{abstract}

Thomas A. Neubauer. Geological-Paleontological Department, Natural History Museum Vienna, Burgring 7, 1010 Vienna, Austria thomas.neubauer@nhm-wien.ac.at

Elisavet Georgopoulou. Geological-Paleontological Department, Natural History Museum Vienna, Burgring 7, 1010 Vienna, Austria elisavet.georgopoulou@nhm-wien.ac.at

Andreas Kroh. Geological-Paleontological Department, Natural History Museum Vienna, Burgring 7, 1010 Vienna, Austria andreas.kroh@nhm-wien.ac.at

Mathias Harzhauser. Geological-Paleontological Department, Natural History Museum Vienna, Burgring 7 , 1010 Vienna, Austria mathias.harzhauser@nhm-wien.ac.at

Oleg Mandic. Geological-Paleontological Department, Natural History Museum Vienna, Burgring 7, 1010 Vienna, Austria oleg.mandic@nhm-wien.ac.at

Daniela Esu. Dipartimento di Scienze della Terra, "Sapienza" University of Rome, P.le A. Moro 5, 00185

Rome, Italy daniela.esu@uniroma1.it

Keywords: freshwater mollusks; database; georeferenced data; Miocene; Pliocene

PE Article Number: 18.1.3T

Copyright: Palaeontological Association April 2015

Submission: 9 August 2014. Acceptance: 31 March 2015

Neubauer, Thomas A., Georgopoulou, Elisavet, Kroh, Andreas, Harzhauser, Mathias, Mandic, Oleg, and Esu, Daniela. 2015. Synopsis of European Neogene freshwater gastropod localities: updated stratigraphy and geography. Palaeontologia Electronica 18.1.3T: 1-7.

palaeo-electronica.org/content/2015/1153-neogene-freshwater-gastropods 


\section{INTRODUCTION}

In 2013 a new project was launched devoted to the statistical assessment and evaluation of Europe's freshwater gastropod faunas during the Neogene (FreshGEN, Neubauer et al., 2014, 2015). In order to allow accurate geographic comparisons of coeval faunas a sound stratigraphy is indispensable. Despite great effort of experts for regional stratigraphy, however, many errors and misclassifications are still found even in modern publications. This involves classical problems like confusion of stratigraphic concepts or controversially discussed correlations of regional stratigraphic units to the international geological timescale. A common example for the first case is the erroneous correlation between the Tortonian of the Mediterranean and the actually much older Badenian (Langhian to Early Serravallian) strata in Paratethys area erroneously attributed to the Tortonian as well (Papp et al., 1978). An example for the latter case is the correlations of the "Paludina beds" (Krstić, 2003; Krstić and Knežević, 2003; Nenadić et al., 2011; Krstić et al., 2012) in Croatian, Hungary, and Serbia and its Romanian counterparts in the Dacian Basin (Lubenescu and Zazuleac, 1985; Papaianopol et al., 2003; Stoica et al., 2007, 2013; Lubenescu and Lubenescu, 2008) or the southern German Kirchberg Formation (Schlickum, 1964, 1966, 1970a, 1970b; Zöbelein, 1983, 1994; Reichenbacher et al., 1998a, 1998b, 2004, 2013; Kowalke and Reichenbacher, 2005) and Silvana beds (Gall, 1972; Schlickum, 1976; Zöbelein, 1985) to the international timescale. Here we present the latest update of the stratigraphic ages as derived from the most recent literature available. In many cases this involves two steps, i.e., the integration of a locality's deposits in a regional framework and the correlation of the latter to the international Geological Time Scale, hence, absolute ages. Especially for cases where information is still wanting or imprecise or for those entirely based on uncertain faunal records, some age attributions certainly will be still incorrect. Therefore, we welcome any feedback by experts for regional stratigraphy to improve this framework, which can be used as basis for future biodiversity analyses. This dataset will not only be relevant for malacologists but will be an essential basis for any work related to the freshwater deposits and respective faunas in general.

\section{METHODS}

A detailed literature review underlies the present work, with data deriving from 569 publications in total. The localities were gathered from 408 of these works (for all supplementary material see online at palaeo-electronica.org/content/2015/ 1153-neogene-freshwater-gastropods). For stratigraphical information 412 publications were used. Several online sources were used for the georeferencing, where information was wanting in the original publications, i.e., Google ${ }^{\mathrm{TM}}$ Maps (maps.google.com), GeoNames geographical database (www.geonames.org), Google ${ }^{\mathrm{TM}}$ Earth 7 software (version 7.1.2.2041), and OpenStreetMap (www.openstreetmap.org/). Additionally consulted offline sources are the lexicon of villages in the Habsburg monarchy (Raffelsperger, 1845-1853) and numerous geological and geographical maps stored in the library of the Geological-Paleontological Department of the Natural History Museum Vienna. Although the general geographic frame is Europe we also integrated Turkey and marginal territories of Azerbaijan, Georgia, and Kazakhstan, because these regions harbor closely related gastropod faunas and the palaeogeographic units studied do not end at the political boundaries of modern Europe.

The stratigraphic chart (Figure 1) is based on the Geological Time Scale 2012 (Gradstein et al., 2012) and includes correlations of major regional stratigraphic frameworks. The herein presented frame is a synthesis of a great many of publications and thus sometimes a balanced compromise between different versions. The data basically derives from the following publications: Wenz (1942), Zöbelein (1994), Steininger et al. (1996), Reichenbacher et al. (1998a, b, 2013), Magyar et al. (1999), Kendall and Clegg (2000), Sacchi and Horváth (2002), Krstić (2003), Popov et al. (2006), Harzhauser and Mandic (2008), Prieto et al. (2009), Kälin and Kempf (2009), Krijgsman et al. (2010), Long and Zalasiewicz (2011), Rocholl et al. (2011), Vasiliev et al. (2011), Magyar and Geary (2012), an der Meulen et al. (2012), Andreescu et al. (2013), Stoica et al. (2013), and ter Borgh et al. (2013).

\section{DATA DESIGN}

The comprehensive list covers a total of 2,930 entries and is considered to include almost all known localities of the European Neogene, which encompasses a defined time interval of 23.032.588 Ma (Gradstein et al., 2012). All except 27 


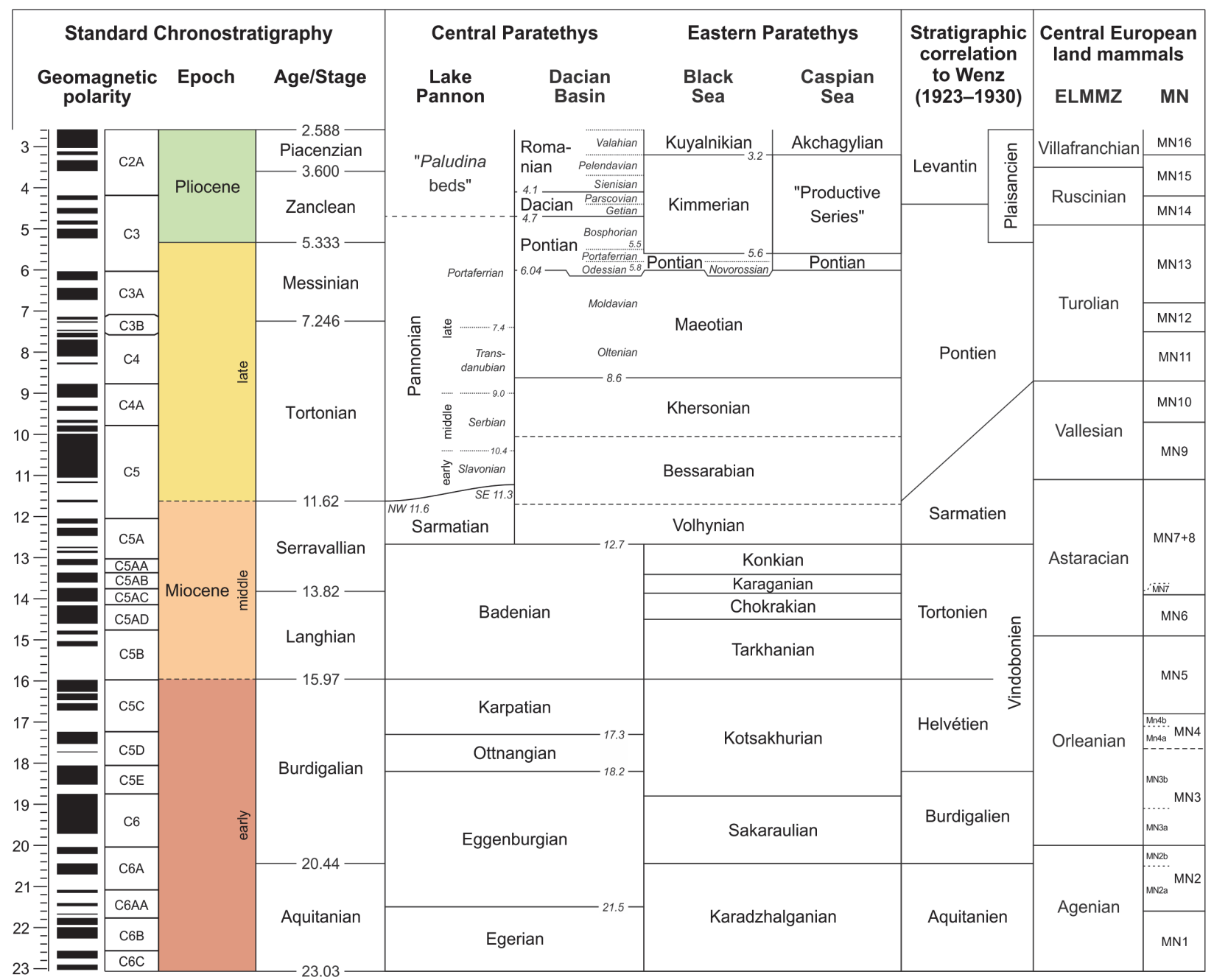

FIGURE 1. Compiled stratigraphic chart based on the Geological Time Scale 2012 (Gradstein et al., 2012) with correlation of regional units and biozones. The boundaries of the intervals used by Wenz (1923-1930) are adapted to those of the current stages. The color code corresponds to the colors in the supplied kml-file. For information about the sources see Methods chapter.

$(<1 \%)$ are fully georeferenced. The latter localities could not be unambiguously matched with modern geographic terms listed in the consulted online and offline sources. For some many possible candidates exist; others, in contrast, are absent from all modern sources. Neither could the exact geographic position of these localities be figured out by re-checking the original publications first mentioning them, due to the lack of precise information.

Figure 2 shows all the localities with geographical data. This map, however, clearly reveals underrepresented areas. North of ca. $52^{\circ}$ latitude surface deposits are of Late Pliocene age or younger. Apart from subsurface strata (e.g., documented in mines and boreholes), older deposits at higher latitudes were eroded during the Ice Ages. Moreover, data from Eastern Europe is scarce, largely resulting from the lack of sediments of that age, but certainly also from the inaccessibility of regional literature.

The dataset (see online at palaeo-electronica.org/content/2015/1153-neogene-freshwatergastropods) provided as Microsoft Excel 97-2003 file (.xls) gives information about geography and stratigraphy of the Neogene localities. To ease usage of the data a Keyhole Markup Language file $(. \mathrm{kml})$ is provided which allows rapid visualization of the data in many GIS systems, including Google $^{\mathrm{TM}}$ Earth and ESRI ${ }^{\circledR}$ ArcGIS ${ }^{\mathrm{TM}}$. The icons in these files are color-coded according to the age of 


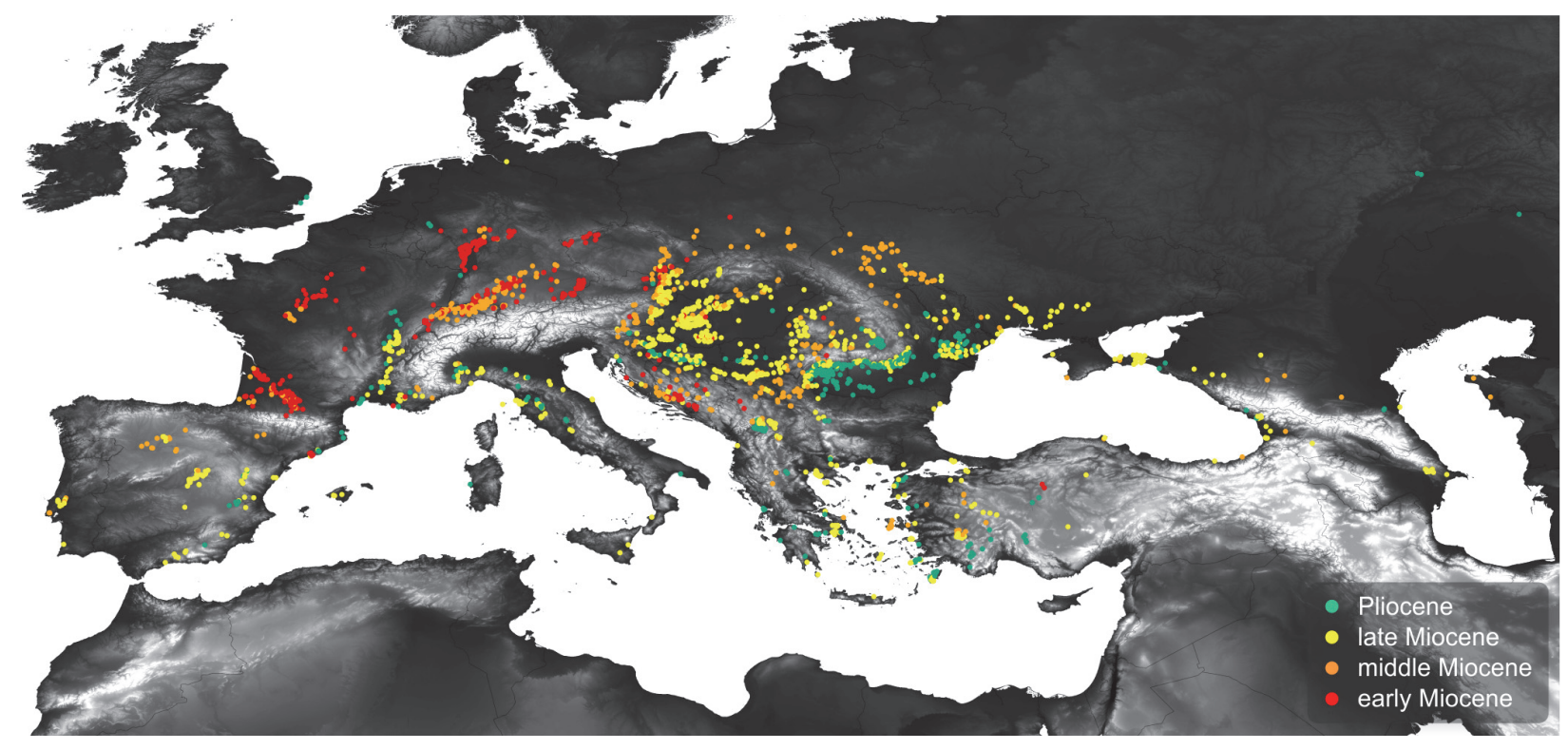

FIGURE 2. European Neogene localities with freshwater gastropod faunas reported in the literature (WGS 84 projection). For complete data see supplied online material. The underlying digital height model derives from Hijmans et al. (2005) and is freely available from www.worldclim.org/.

the locality, in order to provide a first impression of the age distribution of the European freshwater gastropod fossil record. detail:

In the following each field is explained in

ID. Identification number of record as used in the database.

Locality. Name of the locality (occasionally with indication of sample). For records where precise data is unavailable this is equal to the name of the parent administrative unit.

Administrative unit. Parent geographic category, i.e., the village or city the locality belongs to.

Country. Provides information to which country the locality belongs at present.

Alternate spellings. Disused names of the locality and common misspellings found in the literature. Sometimes this involves many different notations, depending on the presence of diacritic marks and/ or hyphenations or shifting political affiliations in the past.

Latitude. Using WGS 84 reference system.

Longitude. Using WGS 84 reference system.

Geographic precision. Specification about the precision of the coordinates $(1=100 \mathrm{~m}$ confidence radius, $2=5 \mathrm{~km}$ confidence radius, $3=20 \mathrm{~km}$ confidence radius, $4=$ only the political district is known). This is important to note, since in many cases the exact position of an outcrop or collecting point is not known, although the coordinates appear very precise with many decimal places.
Stratigraphic age. Age of a locality, occasionally with indication of a lithostratigraphic unit or biozone. For some ambiguous terms the respective geographic realm was stated, since the absolute ages may diverge in different paleogeographic settings (e.g., Sarmatian in the Central vs. Eastern Paratethys). For localities where no updated information was available the most probable stratigraphic attribution was derived from the faunal inventory as determined by the present FreshGEN project team. Mind that the given ages for the localities only refer to layers bearing the recorded freshwater gastropods, hence lacustrine, fluviatile, or marginal marine settings with faunal elements washed in. The total stratigraphic range covered by a locality's deposits might thus be larger.

Age, lower boundary. Absolute age of lower boundary of given stratigraphic interval as derived from the literature.

Age, upper boundary. Absolute age of upper boundary. Both lower and upper values might deviate from the real stratigraphic range, but rather indicate maximum and minimum possible boundaries.

Reference. Full literature reference for the stratigraphical information. In some cases the age classification given in the respective publication has been updated in accordance with current knowledge (e.g., "Tortonian" in the Paratethys area was changed to Badenian). 


\section{ACKNOWLEDGMENTS}

We are grateful to the following people for help with literature and/or stratigraphic classifications: J. Albesa (Universidad de València), D. Alba and I. Casanovas-Vilar (Institut Català de Paleontologia, Barcelona), V.V. Anistratenko (Schmalhausen Institute of Zoology of the Ukrainian National Academy, Kiev), A. Engelbrecht (University of Vienna), M. Gross (Universalmuseum Joanneum, Graz), S. Herzog-Gutsch (Natural History Museum Vienna), I Magyar (Hungarian Natural History Museum, Budapest), N. Krstić (Beograd), G. Mas Gornals (Universitat de les Illes Balears, Palma de Mallorca), V.A. Prysjazhnjuk (Ukrainian Academy of Sciences, Kiev), M.W. Rasser (Staatliches Museum für Naturkunde Stuttgart), and D. Vasilyan (Universität Tübingen). The study was financed by the Austrian Science Fund (FWF project no. P25365-B25: "Freshwater systems in the Neogene and Quaternary of Europe: Gastropod biodiversity, provinciality, and faunal gradients").

\section{REFERENCES}

Andreescu, I., Codrea, V., Lubenescu, V., Munteanu, T., Petculescu, A., Ştiucă, E., and Terzea, E. 2013. New developments in the Upper Pliocene-Pleistocene stratigraphic units of the Dacian Basin (Eastern Paratethys), Romania. Quaternary International, 284:1529.

Gall, H. 1972. Die obermiozäne Fossil-Lagerstätte Sandelzhausen. 4. Die Molluskenfauna (Lamellibranchiata, Gastropoda) und ihre stratigraphische und ökologische Bedeutung. Mitteilungen der Bayerischen Staatssammlung für Paläontologie und Historische Geologie, 12:3-32.

Gradstein, F.M., Ogg, J.G., Schmitz, M.D., and Ogg, G.M. (eds.). 2012. The Geologic Time Scale 2012, 2 volumes. Elsevier, Oxford.

Harzhauser, M. and Mandic, O. 2008. Neogene lake systems of Central and South-Eastern Europe: Faunal diversity, gradients and interrelations. Palaeogeography, Palaeoclimatology, Palaeoecology, 260:417434.

Hijmans, R.J., Cameron, S.E., Parra, J.L., Jones, P.G., and Jarvis, A. 2005. Very high resolution interpolated climate surfaces for global land areas. International Journal of Climatology, 25:1965-1978.

Kälin, D. and Kempf, O. 2009. High-resolution stratigraphy from the continental record of the Middle Miocene Northern Alpine Foreland Basin of Switzerland. Neues Jahrbuch für Geologie und Paläontologie, Abhandlungen, 254:177-325.

Kendall, A.C. and Clegg, N.M. 2000. Pleistocene decalcification of Late Pliocene Red Crag shelly sands from Walton-on-the-Naze, England. Sedimentology, 47:1199-1209.
Kowalke, T. and Reichenbacher, B. 2005. Early Miocene (Ottnangian) Mollusca of the Western Paratethys ontogenetic strategies and palaeo-environments. Geobios, 38:609-635.

Krijgsman, W., Stoica, M., Vasiliev, I., and Popov, V.V. 2010. Rise and fall of the Paratethys Sea during the Messinian Salinity Crisis. Earth and Planetary Science Letters, 290:183-191.

Krstić, N. 2003. Paludinian Beds of Voivodina, p. 77-81. In Papaianopol, I., Marinescu, F., Krstić, N., and Macaleț, R. (eds.), Chronostratigraphie und Neostratotypen. Neogen der Zentrale Paratethys, Bd. X, PI2. Romanien. Editura Academiei Române, București.

Krstić, N. and Knežević, S. 2003. Succession of the Fauna of the Paludinian Beds, p. 83-92. In Papaianopol, I., Marinescu, F., Krstić, N., and Macaleț, R. (eds.), Chronostratigraphie und Neostratotypen. Neogen der Zentrale Paratethys, Bd. X, PI2. Romanien. Editura Academiei Române, București.

Krstić, N., Savić, L., and Jovanović, G. 2012. The Neogene Lakes of the Balkan Land. Annales Géologiques de la Péninsule Balkanique, 73:37-60.

Long, P.E. and Zalasiewicz, J.A. 2011. The molluscan fauna of the Coralline Crag (Pliocene, Zanclean) at Raydon Hall, Suffolk, UK: Palaeoecological significance reassessed. Palaeogeography, Palaeoclimatology, Palaeoecology, 309:53-72.

Lubenescu, V. and Lubenescu, D. 2008. Neogenul superior - strate cu Paludine din România. Studii şi Cercetări de Geologie, 51-53:77-88.

Lubenescu, V. and Zazuleac, D. 1985. Les Viviparidés du Néogène supérieur du Bassin Dacique. Mémoires - L'Institut de Géologie et de Géophysique, 32:77136.

Magyar, I., Geary, D.H., Sütő-Szentai, M., Lantos, M., and Müller, P. 1999. Integrated biostratigraphic, magnetostratigrpahic and chronostratigraphic correlations of the Late Miocene Lake Pannon deposits. Acta Geologica Hungarica, 42:5-31.

Magyar, I. and Geary, D.H. 2012. Biostratigraphy in a Late Neogene Caspian-Type Lacustrine Basin: Lake Pannon, Hungary. In Baganz, O.W., Bartov, Y., Bohacs, K., and Nummedal, D. (eds.), Lacustrine sandstone reservoirs and hydrocarbon systems. AAPG Memoir, 95:255-264.

Nenadić, D., Gaudényi, T., Bogićević, K., and Gulan, Z. 2011. The lower Quaternary boundary in the Southeastern Srem (North Serbia). Bulletin of the Natural History Museum, 4:23-36.

Neubauer, T.A., Harzhauser, M., Kroh, A., Georgopoulou, E., and Mandic, O. 2014. The FreshGEN Database: Freshwater Gastropods of the European Neogene. Accessed at www.marinespecies.org/ freshgen

Neubauer, T.A., Harzhauser, M., Kroh, A., Georgopoulou, E. and Mandic, O. 2015. A gastropod-based biogeographic scheme for the European Neogene freshwater systems. Earth-Science Reviews, 143:98116. 
Papaianopol, I., Marinescu, F., and Macaleț, R. 2003. Les coupes représentatives (stratotypes, faciostratotypes, stratotypes de limite), p. 133-173. In Papaianopol, I., Marinescu, F., Krstić, N., and Macaleț, R. (eds.), Chronostratigraphie und Neostratotypen. Neogen der Zentrale Paratethys, Bd. X, PI2. Romanien. Editura Academiei Române, București.

Papp, A., Cicha, I., and Seneš, J. (eds.). 1978. Chronostratigraphie und Neostratotypen. Miozän der Zentralen Paratethys, Bd. VI, M4. Badenien. Verlag der Slowakischen Akademie der Wissenschaften, Bratislava.

Popov, S.V., Shcherba, I.G., Ilyina, L.B., Nevesskaya, L.A., Paramonova, N.P., Khondkarian, S.O., and Magyar, I. 2006. Late Miocene to Pliocene palaeogeography of the Paratethys and its relation to the Mediterranean. Palaeogeography, Palaeoclimatology, Palaeoecology, 238:91-106.

Prieto, J., Böhme, M., Maurer, H., Heissig, K., and Abdul Aziz, H. 2009. Biostratigraphy and sedimentology of the Fluviatile Untere Serie (Early and Middle Miocene) in the central part of the North Alpine Foreland Basin: implications for palaeoenvironment and climate. International Journal of Earth Sciences, 98:1767-1791.

Raffelsperger, F. 1845-1853. Allgemeines geographisch-statistisches Lexikon aller österreichischen Staaten. 6 Bände. Verlag der k. k. a. p. typo-geographischen Kunstanstalt, Wien.

Reichenbacher, B., Böttcher, R., Bracher, H., Doppler, G., von Engelhardt, W., Gregor, H.-J., Heissig, K., Heizmann, E.P.J., Hofmann, F., Kälin, D., Lemcke, K., Luterbacher, H., Martini, E., Pfeil, F., Reiff, W., Schreiner, A., and Steininger, F.F. 1998a. Graupensandrinne - Ries-Impakt: Zur Stratigraphie der Grimmelfinger Schichten, Kirchberger Schichten und Oberen Süßwassermolasse (nördliche Vorlandmolasse, Süddeutschland). Zeitschrift der Deutschen Geologischen Gesellschaft, 149:127-161.

Reichenbacher, B., Böhme, M., Heissig, K., Prieto, J., and Kossler, A. 2004. New approach to assess biostratigraphy, palaeoecology and past climate in the South German Molasse Basin during the Early Miocene (Ottnangian, Karpatian). Courier Forschungsinstitut Senckenberg, 249:71-89.

Reichenbacher, B., Doppler, G., Schreiner, A., Böttcher, R., Heissig, K. and Heizmann, E.P.J. 1998b. Lagerungsverhältnisse von Grimmelfinger Schichten und Kirchberger Schichten: Kommentar zur "Revision der Stratigraphie der süddeutschen Brackwassermolasse." Zeitschrift der Deutschen Geologischen Gesellschaft, 149:321-326.

Reichenbacher, B., Krijgsman, W., Lataster, Y., Pippèrr, M., Van Baak, C.G.C., Chang, L., Kälin, D., Jost, J., Doppler, G., Jung, D., Prieto, J., Abdul Aziz, H., Böhme, M., Garnish, J., Kirscher, U., and Bachtadse,
V. 2013. A new magnetostratigraphic framework for the Lower Miocene (Burdigalian/Ottnangian, Karpatian) in the North Alpine Foreland Basin. Swiss Journal of Geosciences, 106:309-334.

Rocholl, A., Ovtcharova, M., Schaltegger, U., Wijbrans, J., Pohl, J., Harzhauser, M., Prieto, J., Ulbig, A., and Boehme, M. 2011. A precise and accurate "astronomical" age of the Ries impact crater, Germany: A cautious note on argon dating of impact material. Geophysical Research Abstracts, 13:EGU201113322-7.

Sacchi, M. and Horváth, F. 2002. Towards a new time scale for the Upper Miocene continental series of the Pannonian basin (Central Paratethys). EGU Stephan Mueller Special Publication Series, 3:79-94.

Schlickum, W.R. 1964. Die Molluskenfauna der Süßbrackwassermolasse Niederbayerns. Archiv für Molluskenkunde, 93:1-70.

Schlickum, W.R. 1966. Die Molluskenfauna der Kirchberger Schichten des Jungholzes bei Leipheim/ Donau. Archiv für Molluskenkunde, 95:321-335.

Schlickum, W.R. 1970a. Die Molluskenfauna der Kirchberger Schichten des Chiemsee-Gebietes (Tagesaufschlüsse der Ratzinger Höhe und Kohlenbohrungen BI-B14 im Gebiet Endorf - Wasserburg/Inn - Obing). Geologica bavarica, 63:143-158.

Schlickum, W.R. 1970b. Die Molluskenfauna der Kirchberger Schichten der Bohrung Pliening 101-104 (nordöstlich München). Geologica bavarica, 63:159162.

Schlickum, W.R. 1976. Die in der pleistozänen Gemeindekiesgrube von Zwiefaltendorf a. d. Donau abgelagerte Molluskenfauna der Silvanaschichten. Archiv für Molluskenkunde, 107:1-31.

Steininger, F.F., Bergren, W.A., Kent, D.V., Bernor, R.L., Sen, S., and Agustí, J. 1996. Circum-Mediterranean Neogene (Miocene and Pliocene) Marine Continental Chronologie Correlations of European Mammal Units, p. 7-46. In Bernor, R.L., Fahlbusch, V., and Mittmann, H.-W. (eds.), The Evolution of Western Eurasian Neogene Mammal Faunas. Columbia University Press, New York.

Stoica, M., Lazăr, I., Krijgsman, W., Vasiliev, I., Jipa, D., and Floroiu, A. 2013. Paleoenvironmental evolution of the East Carpathian foredeep during the late Miocene-early Pliocene (Dacian Basin; Romania). Global and Planetary Change, 103:135-148.

Stoica, M., Lazăr, I., Vasiliev, I., and Krijgsman, W. 2007. Mollusc assemblages of the Pontian and Dacian deposits from the Topolog-Argeş area (southern Carpathian foredeep - Romania). Geobios, 40:391-405.

ter Borgh, M., Vasiliev, I., Stoica, M., Knežević, S., Matenco, L., Krijgsman, W., Rundić, L., and Cloetingh, S. 2013. The isolation of the Pannonian basin (Central Paratethys): New constraints from magnetostratigraphy and biostratigraphy. Global and Planetary Change, 103:99-118. 
van der Meulen, A.J., García-Paredes, I., Álvarez-Sierra, M.Á., van den Hoek Ostende, L.W., Hordijk, K., Oliver, A., and Peláez-Campomanes, P. 2012. Updated Aragonian biostratigraphy: Small Mammal distribution and its implications for the Miocene European Chronology. Geologica Acta, 10:159-179.

Vasiliev, I., Iosifidi, A.G., Khramov, A.N., Krijgsman, W., Kuiper, K., Langereis, C.G., Popov, V.V., Stoica, M., Tomsha, V.A., and Yudin, S.V. 2011. Magnetostratigraphy and radio-isotope dating of upper Miocenelower Pliocene sedimentary successions of the Black Sea Basin (Taman Peninsula, Russia). Palaeogeography, Palaeoclimatology, Palaeoecology, 310:163175.

Wenz, W. 1923-1930. Fossilium Catalogus I: Animalia. Gastropoda extramarina tertiaria. W. Junk, Berlin.

Wenz, W. 1942. Die Mollusken des Pliozäns der rumänischen Erdöl-Gebiete als Leitversteinerungen für die Aufschluß-Arbeiten. Senckenbergiana, 24:1293.
Zöbelein, H.K. 1983. Die Vorlandmolasse bei Günzburg a. d. Donau und Heggbach bei Biberach a. d. Riß im Rahmen des Süddeutschen Jungtertiärs. Mitteilungen der Bayerischen Staatssammlung für Paläontologie und Historische Geologie, 23:151-187.

Zöbelein, H.K. 1985. Stratigraphie der nördlichen und teils mittleren Vorlandmolasse zwischen Hegau und Isar anhand von 11 Profilen. Mitteilungen der Bayerischen Staatssammlung für Paläontologie und Historische Geologie, 25:209-273.

Zöbelein, H.K. 1994. Die Kirchberger Typusschichten an der Iller (Untermiozän, Vorlandmolasse Württembergs) und ihre stratigraphisch-paläogeographischen Beziehungen. Mitteilungen der Bayerischen Staatssammlung für Paläontologie und Historische Geologie, 34:47-108. 